\title{
Targeted Natural Killer Cell-Based Adoptive Immunotherapy for the Treatment of Patients with NSCLC after Radiochemotherapy: A Randomized Phase II Clinical Trial Ac
}

Gabriele Multhoff $f^{1,2}$, Sophie Seier ${ }^{1}$, Stefan Stangl ${ }^{2}$, Wolfgang Sievert ${ }^{2}$, Maxim Shevtsov ${ }^{2,3}$, Caroline Werner ${ }^{2}$, A. Graham Pockley ${ }^{4}$, Christiane Blankenstein ${ }^{5}$, Martin Hildebrandt ${ }^{6}$, Robert Offner ${ }^{7}$, Norbert Ahrens ${ }^{7}$, Konrad Kokowski ${ }^{8}$, Matthias Hautmann ${ }^{9}$, Claus Röde ${ }^{10}$, Rainer Fietkau ${ }^{11}$, Dorota Lubgan ${ }^{11}$, Rudolf Huber ${ }^{12}$, Hubert Hautmann ${ }^{13}$, Thomas Duell ${ }^{14}$, Michael Molls ${ }^{1}$, Hanno Specht ${ }^{1}$, Bernhard Haller ${ }^{15}$, Michal Devecka', Andreas Sauter ${ }^{16}$, and Stephanie E. Combs ${ }^{1,17,18}$

\section{ABSTRACT}

Purpose: Non-small cell lung cancer (NSCLC) is a fatal disease with poor prognosis. A membrane-bound form of $\mathrm{Hsp} 70$ ( $\mathrm{mHsp} 70)$ which is selectively expressed on high-risk tumors serves as a target for mHsp70-targeting natural killer (NK) cells. Patients with advanced mHsp70-positive NSCLC may therefore benefit from a therapeutic intervention involving $\mathrm{mHsp} 70$-targeting NK cells. The randomized phase II clinical trial (EudraCT2008-002130-30) explores tolerability and efficacy of ex vivo-activated NK cells in patients with NSCLC after radiochemotherapy (RCT).

Patients and Methods: Patients with unresectable, mHsp70positive NSCLC (stage IIIa/b) received 4 cycles of autologous NK cells activated ex vivo with TKD/IL2 [interventional arm (INT)] after RCT (60-70 Gy, platinum-based chemotherapy) or RCT alone [control arm (CTRL)]. The primary objective was progression-free

\section{Introduction}

Lung cancer remains a major health burden with a mortality rate of almost 1.6 million deaths worldwide per year (1). Despite aggressive, combined treatment regimens consisting of simultaneous radiotherapy (up to $70 \mathrm{~Gy}$ ) and platinum-based chemotherapy, tumor control and overall survival (OS) in patients with unresectable, advanced non-small cell lung cancer (NSCLC) remain poor with an OS of less than 2 years (1-5). We have previously reported that the stress-inducible Hsp70, which is frequently over- survival (PFS), and secondary objectives were the assessment of quality of life (QoL, QLQ-LC13), toxicity, and immunobiological responses.

Results: The NK-cell therapy after RCT was well tolerated, and no differences in QoL parameters between the two study arms were detected. Estimated 1-year probabilities for PFS were 67\% [95\% confidence interval (CI), 19\%-90\%] for the INT arm and $33 \%$ (95\% CI, 5\%-68\%) for the CTRL arm ( $P=0.36,1$-sided logrank test). Clinical responses in the INT group were associated with an increase in the prevalence of activated NK cells in their peripheral blood.

Conclusions: Ex vivo TKD/IL2-activated, autologous NK cells are well tolerated and deliver positive clinical responses in patients with advanced NSCLC after RCT.
'Department Radiation Oncology, Klinikum rechts der Isar, TU München, (TUM),
Munich, Germany. ${ }^{2}$ Radiation Immuno-Oncology, Center for Translational
Cancer Research TUM (TranslaTUM), Munich, Germany. Institute of Cytology
of the Russian Academy of Sciences (RAS), St. Petersburg, Russia. ${ }^{4}$ John van
Geest Cancer Research Centre, Nottingham Trent University, Nottingham,
United Kingdom; and multimmune GmbH, Munich, Germany. ${ }^{5}$ Münchner Stu-
dienzentrum CCC, TUM, Munich, Germany. ${ }^{6}$ TUMCells, TUM School of Medicine,
Munich, Germany. ${ }^{7}$ Department of Transfusion Medicine, University Hospital
Regensburg, Regensburg, Germany. ${ }^{8}$ Pneumology and Pneumologic Oncology,
Klinikum Bogenhausen, Munich, Germany. ${ }^{9}$ Department of Radiation Oncology,
University Hospital Regensburg, Regensurg, Germany. ${ }^{10}$ Department of Radio-
therapy and Oncology, Goethe University Frankfurt, Frankfurt, Germany.
${ }^{11}$ Department of Radiation Oncology, Friedrich-Alexander-Universität Erlan-
gen-Nürnberg (FAU), Erlangen, Germany. ${ }^{2}$ Division of Respiratory Medicine
and Thoracic Oncology Centre Munich and Thoracic Oncology Centre Munich,
University München, LMU, Munich, Germany. ${ }^{13}$ Pneumology Group Med I, Klini-
kum rechts der Isar, TUM, Munich, Germany. ${ }^{14}$ Asklepios Lung Hospital München- expressed in many malignant tumor types, including advanced NSCLC, is selectively presented on the cell surface of many tumor, but not normal, cells and therefore serves as a tumor-specific target (6). We have also demonstrated that the expression density of a membrane-bound form of Hsp70 (mHsp70) is further increased by radio- and/or chemotherapy and hyperthermia (7-10); that it is more highly expressed on aggressive and metastatic diseases (11); and, importantly, that it is recognized by NK cells that have been prestimulated with an Hsp70-derived peptide (“TKD”; TKDNNLLGRFELSG, aa 450-463) and low-dose IL2

Gauting, Thoracal Pneumology, LMU, Munich, Germany. ${ }^{15}$ Institute of Medical Informatics, Statistics and Epidemiology, TUM, Munich, Germany. ${ }^{16}$ Institute of Radiology, TUM, Munich, Germany. ${ }^{17}$ Institute of Radiation Medicine (IRM), Helmholtz Zentrum München (HMGU), Neuherberg, Germany. ${ }^{18}$ Deutsches Konsortium für Translationale Krebsforschung (DKTK), Partner Site Munich, Germany.

Note: Supplementary data for this article are available at Clinical Cancer Research Online (http://clincancerres.aacrjournals.org/).

Corresponding Author: Gabriele Multhoff, Technische Universität München, Einstein Str. 25, D-81675 Munich, Germany. Phone: 49-89-4140-4514; Fax: 4989-4140-4299; E-mail: gabriele.multhoff@tum.de

Clin Cancer Res 2020;XX:XX-XX

doi: 10.1158/1078-0432.CCR-20-1141

(C)2020 American Association for Cancer Research. 


\section{Translational Relevance}

In this phase II trial, it was shown that progression-free survival was improved in patients who received ex vivo Hsp70-stimulated natural killer (NK) cells compared with patients receiving only standard-of-care radiochemotherapy. Clinical responses of the interventional (INT) group were associated with an increased prevalence of activated mHsp70-targeting NK cells in the peripheral blood, and elevated extracellular Hsp70 levels were predictive for therapy response. Together with promising data of a case study, these findings provide the basis for future clinical approaches consisting of radiochemotherapy and/or surgery, mHsp70-targeting NK cells, and immune checkpoint inhibition in the treatment of patients with advanced non-small cell lung cancer. Because Hsp70 is not only present on the plasma membrane of lung tumors, but also on a large variety of other tumor entities, the combined immunotherapeutic approach might also exert beneficial effects in patients with breast, colorectal, pancreas, and head and neck cancers; glioblastoma; and hematologic diseases.

(100 IU/mL, TKD/IL2; ref. 12). Therefore, we propose that patients with advanced mHsp70-positive NSCLC will benefit from a therapeutic intervention involving $\mathrm{mHsp} 70$-targeting $\mathrm{NK}$ cells. Of relevance is the fact that feasibility and safety of an adoptive transfer of ex vivo-stimulated, autologous NK cells have already been demonstrated in a phase I clinical trial involving 12 patients with metastatic colorectal cancer and NSCLC (13) receiving up to 6 NK-cell reinfusion cycles, and in a subsequent case study in which a patient received up to $9 \mathrm{NK}$-cell reinfusion cycles (14). Herein, we report on the outcome of a randomized, investigator-initiated phase II clinical study which explored tolerability and efficacy of ex vivo-activated autologous NK cells in patients with advanced stage NSCLC after radiochemotherapy (RCT). The ex vivo stimulation of NK cells is a prerequisite because it has been demonstrated for other tumor entities that NK cells in patients with solid tumors are in a cytolytic inactive, resting stage (15).

\section{Materials and Methods}

\section{Patients, ethics, and inclusion and exclusion criteria}

Sixteen patients $[8$ interventional arm (INT), 8 control arm (CTRL)] with histologically proven, inoperable, clinical stage IIIa/b squamous cell lung cancer (a subtype of NSCLC) were randomized and analyzed in the phase II clinical trial (16). Approval for the study was obtained by the Institutional Ethical Review Boards of all participating clinical centers. Written informed consent was obtained from all patients before start of therapy. A separate approval by the Institutional Ethical Review Boards was given for screening serum levels of Hsp70 and immunophenotyping of blood lymphocytes in patients in the prestudy part of the trial at study visits VS (Hsp70 screening) and V0 (after RCT). Inclusion and exclusion criteria are summarized in Supplementary Table S1. The study was conducted in accordance to ethical guidelines as determined by the Declaration of Helsinki.

Patient recruitment was difficult because immune checkpoint inhibitor therapies were competing for the same patient collective at the same time. After approval of durvalumab, all patients with NSCLC in stage III were treated with immune checkpoint inhibitor therapy, and the NK study had to be closed.

\section{Prestudy part: Hsp70 screening}

As shown in a CONSORT diagram, a total of 120 patients were screened for their tumor mHsp70 status, as determined by analyzing circulating levels of Hsp70 using the lipHsp70 ELISA (17). Eighty-six patients $(72 \%)$ were categorized as being $\mathrm{mHsp} 70$ positive. Thirty patients were diagnosed as having stage IIIa/b disease; 56 were in a metastasized tumor stage (IV), diagnosed as SCLC, or had an adenocarcinoma histology; 3 patients declined participation; and 11 patients refused to get RCT (Fig. 1A, upper part).

\section{Study treatment}

Patients with mHsp70-positive tumors were staged regularly at defined time intervals following standard RCT (60-70 Gy, platinumbased chemotherapy) in the CTRL arm. In the INT arm, patients with mHsp70-positive tumors received TKD/IL2-activated, autologous NK cells (somatic cell therapy, plasma-derived medicinal product, IMP) subsequent to standard RCT (60-70 Gy, platinum-based chemotherapy). Patients with an insufficient leukapheresis product or a failure of NK-cell activation (as defined by less than $3 \%$ of NK cells in the lymphocyte population and/or less than 1.2-fold upregulation in the intensity of CD94 expression on NK cells) were excluded from the study. Tumor staging in both groups was performed using PET/CT or CT scanning.

\section{Leukapheresis, ex vivo stimulation of human NK cells with TKD/IL-2 and reinfusion protocol}

Within 1 to 2 months after completion of RCT, leukocyte concentrates were obtained from patients by a 3- to 4-hour leukapheresis (COBE Spectra Apheresis System) centrally at the University Hospital Regensburg, Germany. Peripheral blood lymphocytes (PBL) were isolated by density gradient centrifugation in a closed SEPAX Cell Processing System (Biosafe) and resuspended in CellGro SCGM stem cell medium (CellGenix). After counting, PBLs $\left(5-10 \times 10^{6} / \mathrm{mL}\right.$ in CellGro medium) were incubated with $2 \mu \mathrm{g} / \mathrm{mL}$ GMP-grade TKD peptide (Bachem) and $100 \mathrm{IU} / \mathrm{mL}$ recombinant IL2 (Proleukin, Novartis) in $250 \mathrm{~mL}$ Teflon bags (Vue-Life-118, CellGenix) under gentle rotation at $37^{\circ} \mathrm{C}, 5 \% \mathrm{v} / \mathrm{v} \mathrm{CO}_{2}$ in a humidified atmosphere ( $90 \%$; Heraeus) for 3 to 5 days in a GMP-accredited laboratory (TUMCells). Treated cells were harvested, washed twice, and resuspended in Ringer's lactate solution $(500 \mathrm{~mL})$ containing $0.1 \% \mathrm{v} / \mathrm{v}$ human serum albumin. Sterility testing of intermediate and final products was performed before/after stimulation and before reinfusion. TKD/IL2, autologous PBLs were reinfused into the patient by intravenous injection over 30 to 60 minutes using a stem cell reinfusion set. The time period between washing of the cells until reinfusion did not last more than 24 hours. Patients were treated up to 4 times with ex vivo-activated autologous NK cells every 2 to 6 weeks between study visits V1 and V5.

\section{Laboratory parameters and flow cytometric analysis of PBLs}

Routine laboratory parameters (differential blood counts, RBC parameters, and white blood cell counts) and blood chemistry (creatinine, AST/SGOT, ALT/SGPT, $\gamma$-GT, and LDH) were determined after each therapy (RCT, NK cells) and every 3 months in the follow-up period.

Blood samples for effector cell phenotyping were taken at visits VS (Hsp70 screening), V0 (after RCT), V1 (randomization), and in the follow-up periods V5 (3-4 months after randomization), V6 (6-7 months after randomization), V7 (9-12 months after randomization), and V8 (18 months after randomization, end of the 
A

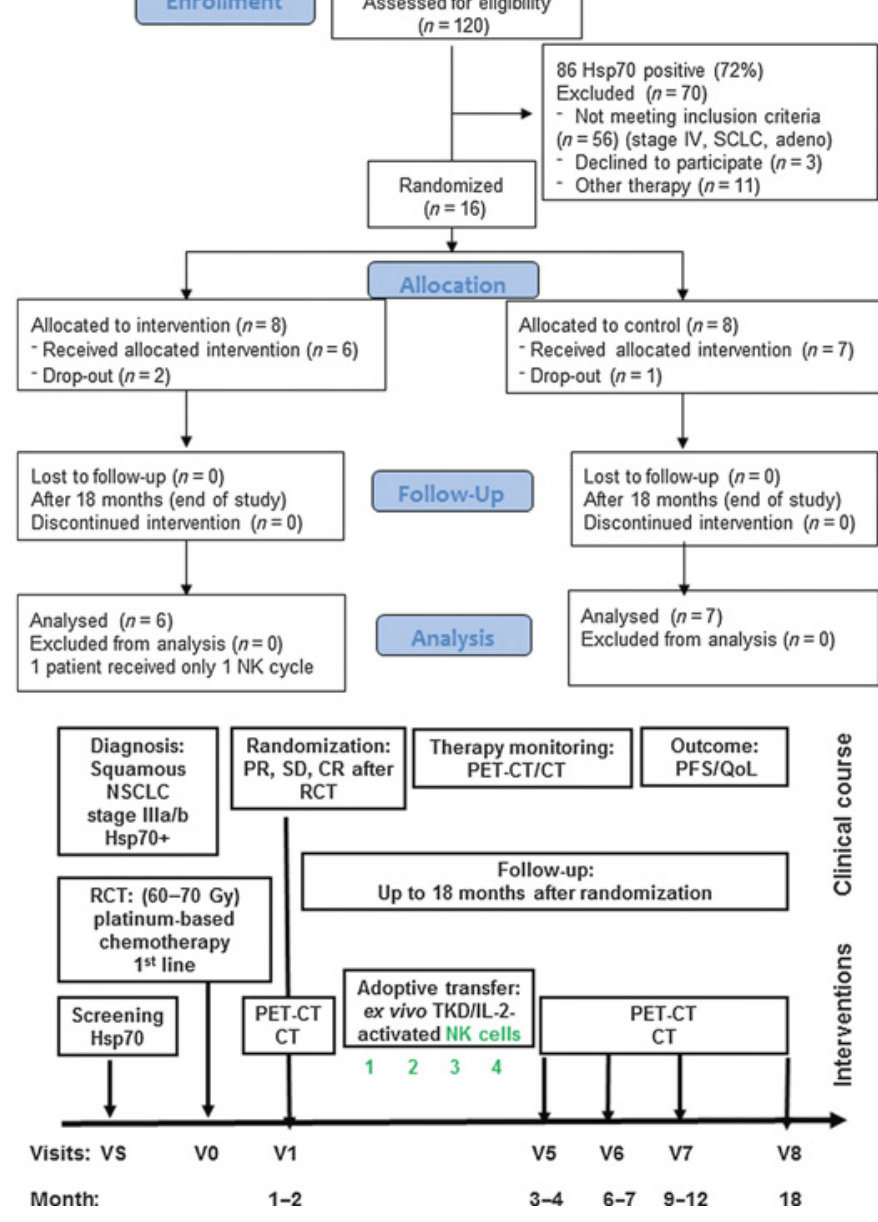

B
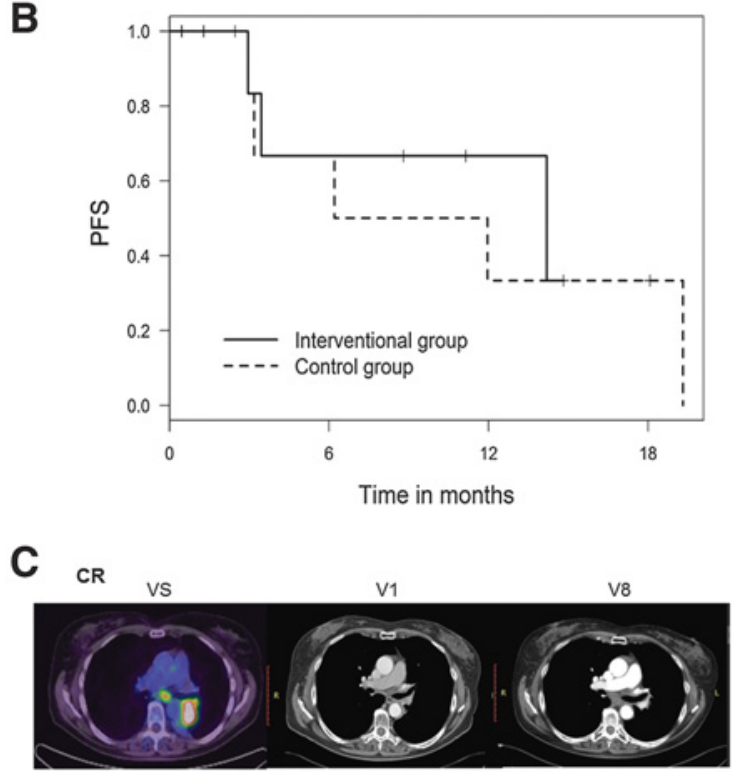

PR

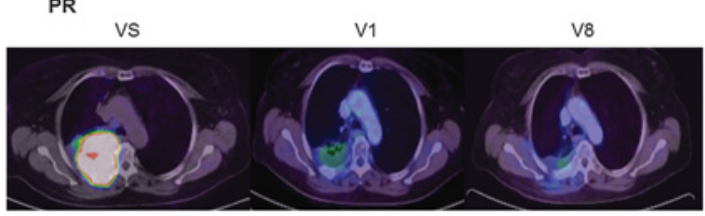

PD

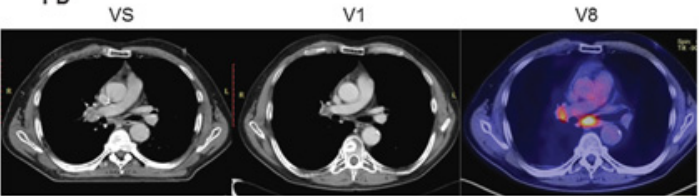

Figure 1.

A, CONSORT diagram and schematic representation of the clinical course and interventions of the randomized phase II clinical trial. NK-cell treatment cycles 1 to 4 are marked in green. Visits for blood donations and timelines (months) are indicated at the bottom. B, Kaplan-Meier curves for PFS of patients of the INT (solid line) and CTRL (dotted line) arms of all analyzed patients. C, Representative CT and PET-CT scans (axial soft-tissue window) of patients of the INT arm with complete response (CR), partial response (PR), and progressive disease (PD) before and after therapies: screening for mHsp70 (VS), 1-2 months after $\mathrm{RCT}$ at randomization (V1), last follow-up 18 months after randomization (V8). (Continued on the following page.)

study). The presence of the following lymphocyte subsets in the peripheral blood of patients at the indicated study visits was determined by multiparameter flow cytometry using a BD FACSCalibur flow cytometer (BD Biosciences): $\mathrm{CD}^{-} / \mathrm{CD} 19^{+} \mathrm{B}$ cells, $\mathrm{CD}_{4} 5^{+} / \mathrm{CD}^{+} \mathrm{T}$ cells, $\mathrm{CD}^{+} / \mathrm{CD}^{+}$helper $\mathrm{T}$ cells, $\mathrm{CD}^{+} / \mathrm{CD}^{+}$ cytotoxic $\mathrm{T}$ cells, $\mathrm{CD}^{+} / \mathrm{CD}^{+} / \mathrm{CD} 25^{+} / \mathrm{FoxP}^{+}$regulatory $\mathrm{T}$ cells (Treg), $\mathrm{CD}^{+} / \mathrm{CD}^{2} 6^{+}$NK-like $\mathrm{T}(\mathrm{NKT})$ cells, $\mathrm{CD}^{+} / \mathrm{CD}^{+} 6^{+} \mathrm{NKT}$ cells, $\mathrm{CD}^{+} / \mathrm{NKG}^{2} \mathrm{D}^{+} \mathrm{NKT}$ cells, $\mathrm{CD}^{+} / \mathrm{CD} 9^{+} \mathrm{NKT}^{-}$cells, $\mathrm{CD}^{-} /$ $\mathrm{CD}^{+} 6^{+} \mathrm{NK}$ cells, $\mathrm{CD} 3^{-} / \mathrm{CD} 16^{+} \mathrm{NK}$ cells, $\mathrm{CD} 3^{-} / \mathrm{CD} 94^{+} \mathrm{NK}$ cells, $\mathrm{CD}^{-} / \mathrm{NKG}^{-} \mathrm{D}^{+} \mathrm{NK}$ cells, $\mathrm{CD}^{-} / \mathrm{NKp}^{-} 0^{+} \mathrm{NK}$ cells, $\mathrm{CD} 3^{-} / \mathrm{NKp} 46^{+}$ $\mathrm{NK}$ cells, and $\mathrm{CD}^{-} / \mathrm{CD} 9^{+} \mathrm{NK}$ cells. The antibody combinations used for the study have been described previously (18).

\section{Determination of serum Hsp70 levels}

Blood samples $(7.5 \mathrm{~mL})$ were collected in EDTA KE separator tubes (S-Monovette Z, Sarstedt) at diagnosis (VS), after RCT (V1), and 3 to 4 months after randomization (V5). EDTA blood was centrifuged at $1,500 \mathrm{~g}$ for 15 minutes. For serum separation, blood was allowed to clot for 15 minutes at room temperature and then centrifuged at $750 \mathrm{~g}$ for 10 minutes. Aliquots of plasma/ serum $(100-300 \mu \mathrm{L})$ were stored at $-80^{\circ} \mathrm{C}$ until further analysis. Hsp70 concentrations were determined using the lipHsp70 ELISA which detects both exosomal and free Hsp70 in serum/ plasma (17).

\section{Statistical methods}

\section{Sample size calculation}

Sample size calculations were based on the following. Previous studies have reported progression-free survival (PFS) probability after 18 months for a combined sample of unselected (mHsp70positive and -negative) patients with NSCLC that had survived without tumor progression for at least 5 months after the start of RCT to be approximately $0.30(3,4)$ without immune checkpoint inhibitors (19). The probability for PFS for patients with more highly aggressive mHsp70-positive tumors for stable disease at the end of RCT was assumed to be 0.20 and that the 18 -month 
D
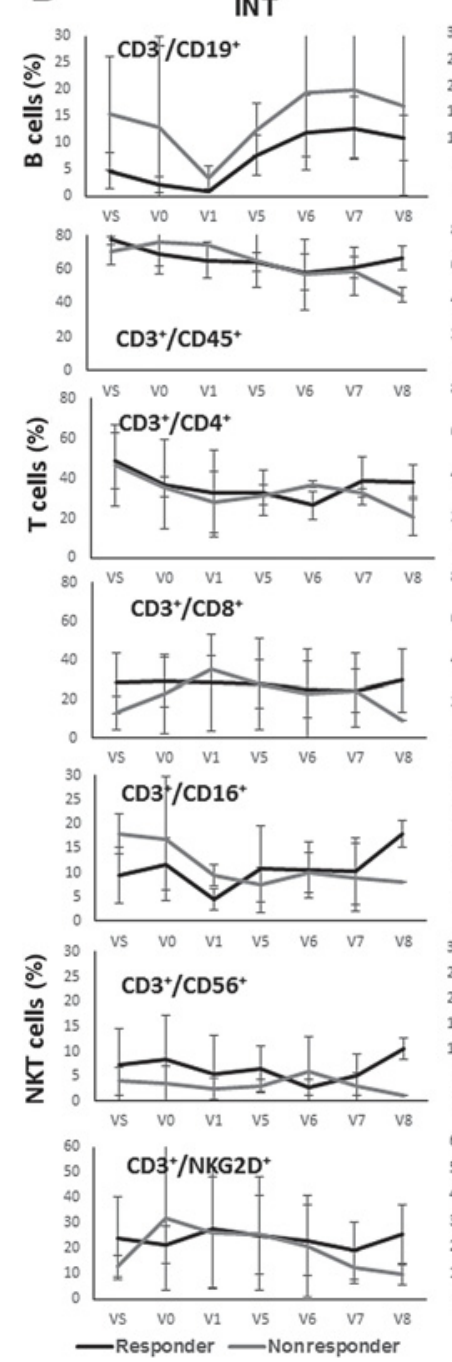

CTRL
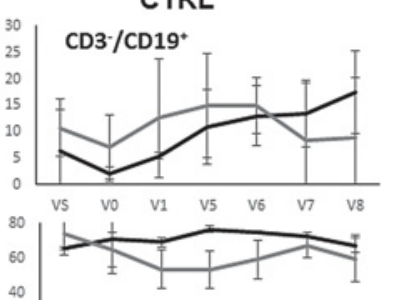

$\mathrm{CD}^{*} / \mathrm{CD} 5^{*}$
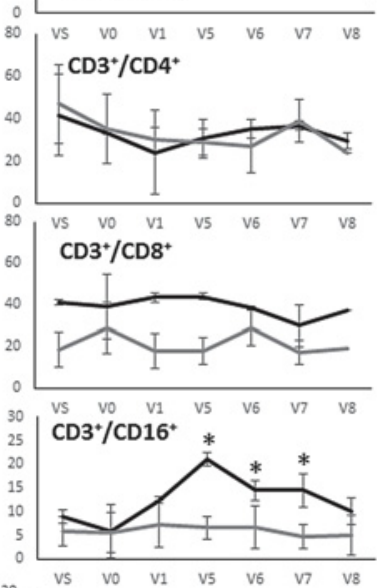

$\mathrm{CD}^{+} / \mathrm{CD}^{2} 6^{+}$
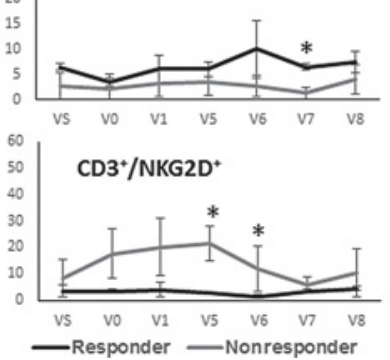

INT
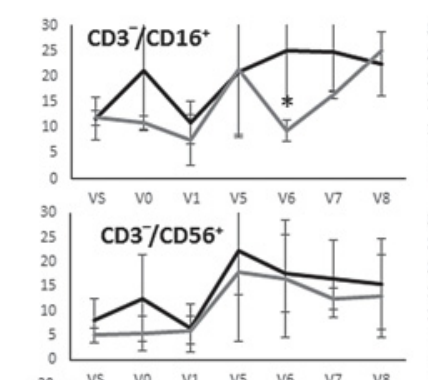

$\mathrm{CD}^{-} / \mathrm{CD}^{\circ} 4^{+}$
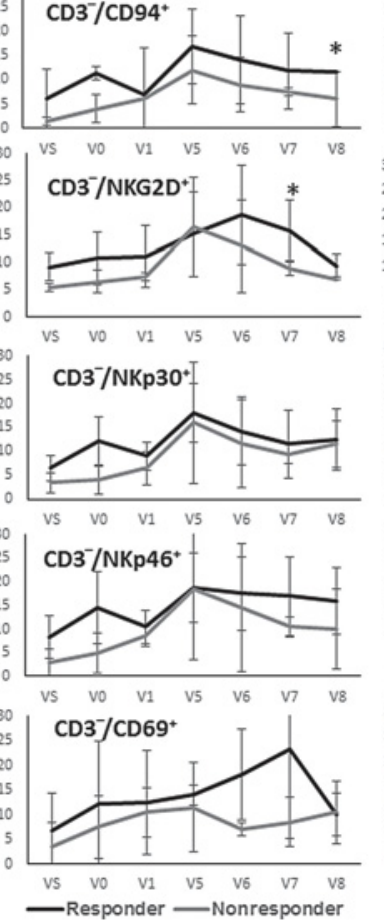

CTRL
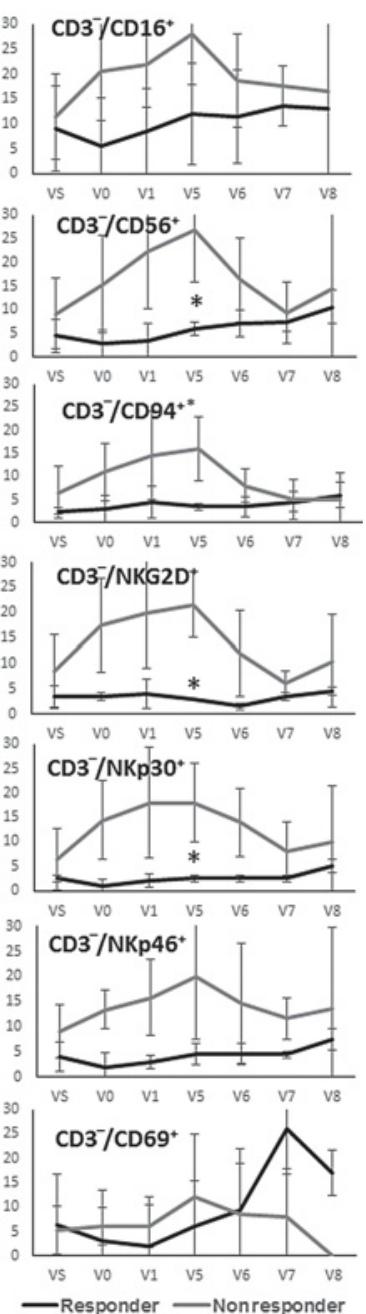

Figure 1.

(Continued.) D, Comparison of the proportion of different lymphocyte subpopulations in responders and nonresponders of the INT and CTRL arm at visits VS (screening), VO (after RCT), V1 (1-2 months after RCT at randomization), V5 (3-4 months after randomization), V6 (6-7 months after randomization), V7 (9-12 months after randomization), and V8 (18 months after randomization). Lymphocyte subpopulations were assessed using the following antibody combinations: $\mathrm{CD}^{-} / \mathrm{CD}^{+} 9^{+} \mathrm{B}$ cells; $\mathrm{CD}^{+} / \mathrm{CD} 45^{+} \mathrm{T}$ cells; $\mathrm{CD}^{+} / \mathrm{CD}^{+} \mathrm{T}$ helper cells; $\mathrm{CD}^{+} / \mathrm{CD}^{+} \mathrm{cytotoxic}^{\mathrm{T}} \mathrm{cells}$; $\mathrm{CD}^{+} / \mathrm{CD} 6^{+}, \mathrm{CD}^{+} / \mathrm{CD} 6^{+}$,

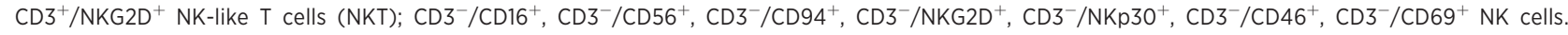
Responders of the INT arm, $n=4$; nonresponders of the INT arm, $n=2$; responders of the CTRL arm, $n=2$; nonresponders of the CTRL arm, $n=5$. ${ }^{*} P \leq 0.05$. (Continued on the following page.)

PFS probability would improve to at least 0.45 , translating to an $\mathrm{HR}$ of 0.50

\section{Analysis sets}

The intention to treat (ITT) group consists of all randomized subjects who received at least one study medication. The per protocol population consists of all ITT patients without major protocol violations, as defined during the Blinded Data Review Meeting. The safety population consists of all randomized subjects with any postrandomization data. All efficacy analyses were performed "as randomized" on the ITT population and "as treated" on the per protocol populations. The ITT population was the primary analysis population. All safety analyses were based on the safety population. Safety analysis was performed "as treated."

\section{Efficacy analyses}

PFS between both study groups was compared using a log-rank test on a 1 -sided level of significance of $\alpha=5 \%$. Estimated 1-year PFS probabilities and median PFS times are reported with 95\% confidence intervals $(95 \% \mathrm{CI})$. A Cox regression model was fitted to the data in order to estimate the HR (with $95 \% \mathrm{CI}$ ) between the study groups. Due to the small sample size, no subgroup analyses were performed. Analysis of the primary endpoint was also performed on the per protocol set. Secondary analyses were performed in an explorative manner. 
Figure 1.

(Continued.) E, Representative dot blot analysis of responders of the INT versus CTRL arms at V1 (1-2 months after RCT at randomization), V5 (34 months after randomization), V6 (6-7 months after randomization), and V8 (18 months after randomization). The following lymphocyte subpopulations are shown in the different quadrants: $\mathrm{CD}^{+} / \mathrm{CD}^{+} \mathrm{T}$ helper cells; $\mathrm{CD}^{+} / \mathrm{CD}^{+}$ cytotoxic $\mathrm{T}$ cells; $\mathrm{CD}^{+} / \mathrm{CD}^{+} 6^{+}, \mathrm{CD}^{+} / \mathrm{CD}^{2} 6^{+}$ $\mathrm{CD3}^{+} / \mathrm{NKG}^{2} \mathrm{D}^{+}, \mathrm{CD}^{+} / \mathrm{CD} 69^{+}$NK-like $\mathrm{T}$ cells (NKT); and $\mathrm{CD}^{-} / \mathrm{CD}^{-} 6^{+}, \mathrm{CD}^{-} / \mathrm{CD}^{-} 6^{+}, \mathrm{CD}^{-} /$ $\mathrm{CD}^{+} 4^{+}, \mathrm{CD}^{-} / \mathrm{NKG}^{-} \mathrm{D}^{+}, \mathrm{CD}^{-} / \mathrm{NKp}^{-} 0^{+}, \mathrm{CD}^{-} /$ $\mathrm{CD}_{4} 6^{+}, \mathrm{CD}^{-} / \mathrm{CD} 69^{+} \mathrm{NK}$ cells. The proportions of all lymphocyte subsets are shown in black, and the proportions of $\mathrm{CD}^{-}$NK cells are shown in green. The $C D 4 / C D 8$ ratios and the fold increase in $\mathrm{CD}^{-} / \mathrm{CD} 6^{+}, \mathrm{CD}^{-} / \mathrm{CD}^{-} 4^{+}$, and $\mathrm{CD}^{-} / \mathrm{NKG} \mathrm{D}^{+}$ NK-cell subsets at V5, V6, and V8 compared with $\mathrm{V} 1$ are shown below the dot blot graphs. (Continued on the following page.)
E
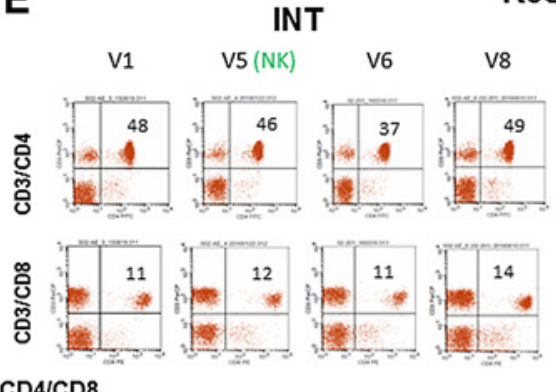

\begin{abstract}
ratios 4.4
\end{abstract}
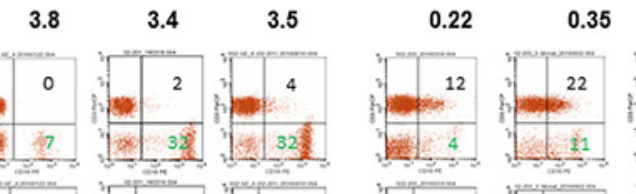

CTRL
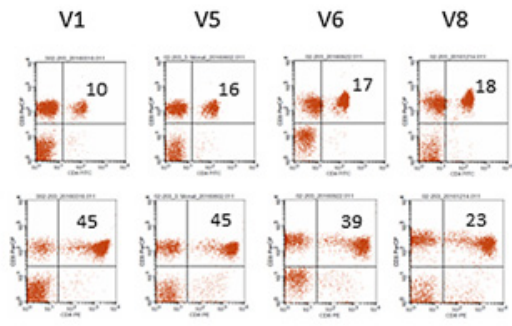

응
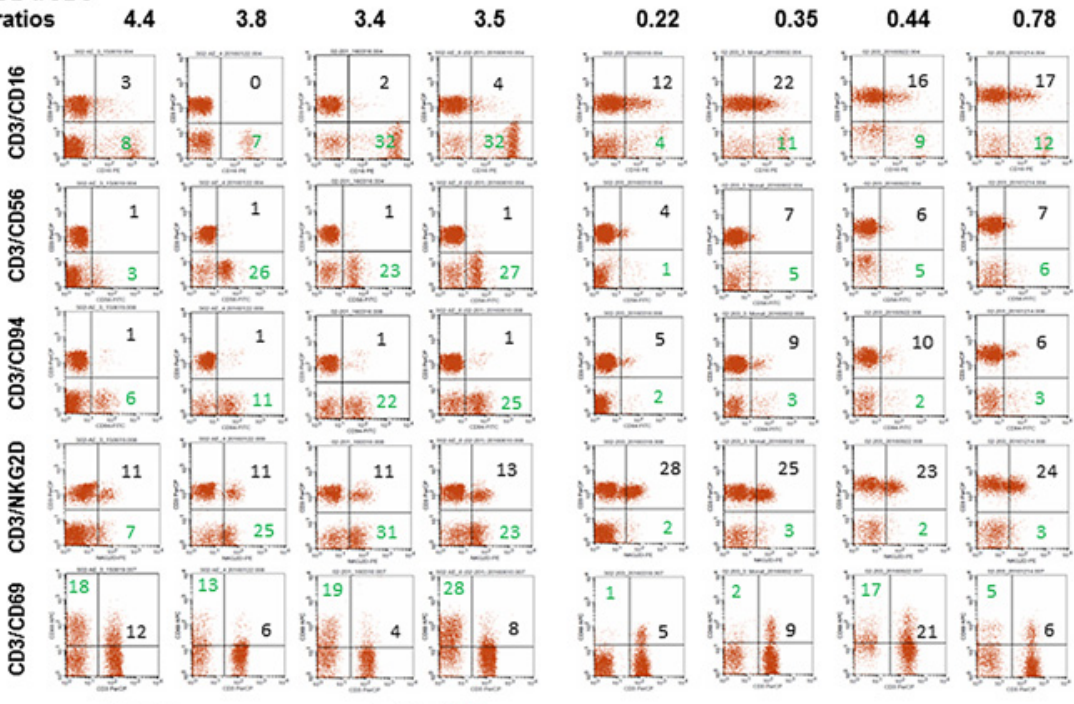

Fold-increase compared to $\mathrm{V} 1$ (NK)

$\begin{array}{llll}\text { CD56 } & 8.6 \mathrm{x} & 7.0 \mathrm{x} & 9.0 \mathrm{x} \\ \text { CD94 } & 1.8 \mathrm{x} & 7.3 \mathrm{x} & 4.2 \mathrm{x} \\ \text { NKG2D } & 3.6 \mathrm{x} & 4.4 \mathrm{x} & 3.3 \mathrm{x}\end{array}$

Distributions of the sum score of the QLQ-C30 questionnaire are depicted by boxplots, with mean values and standard deviations being presented for both groups. Mean values between study groups at relevant timepoints were compared using two-sample $t$ tests. The response category according to immune-related response criteria (irRC) and RECIST1.1 at the last available assessment of each patient was determined and used to describe the tumor response. Distribution of response categories for both study groups is given.

\section{Safety analyses}

Adverse events (AE) and severe AEs (SAE) were classified according to CTCAEV.V4.0 and coded according to MedDRAV17.0 English. Frequencies of observed $\mathrm{AE}$ and SAE are presented by System Organ Class and Preferred Term in both study groups. For assessing toxicity, the maximum observed AE intensity was derived for each included patient. Proportions of patients with at least one AE of grade 3 or higher (defined as a toxic event) were compared using the Fisher exact test. Frequencies of performed apheresis and successful reinfusions are provided for each patient allocated to the INT group. Distributions of increases in the density of CD94 expression on NK cells, a surrogate marker for confirming NK-cell activation and their reactivity against $\mathrm{mHsp} 70$-positive tumors, are presented as the mean, standard deviation, minimum, and maximum for each treatment cycle.

\section{Results}

\section{Study treatment}

The clinical course, therapeutic interventions, study visits, and time scale of patients of the INT arm are provided in Fig. 1A (lower part). After screening (VS), patients with mHsp70-positive, nonresectable NSCLC stage IIIa/b received standard first-line simultaneous platinum-based RCT (60-70 Gy; V0). An mHsp70-positive tumor phenotype was confirmed by elevated exosomal Hsp70 serum levels (above a threshold of $7.4 \mathrm{ng} / \mathrm{mL}$ ), as determined by the lipHsp70 ELISA (17). mHsp70 could not be determined on tumor cells because it was not allowed to get biopsies due to ethical restrictions.

Patients who completed RCT without progression according to routine CT were randomized into the trial within 1 to 2 months after RCT (V1). Patients of the INT arm were treated up to 4 times with ex vivo TKD/IL2-activated, autologous NK cells as a somatic cell therapy (plasma-derived medicinal product, IMP) every 2 to 6 weeks subsequent to RCT. Patient characteristics (Table 1A) and the absolute numbers of reinfused PBLs and $\mathrm{CD}^{-} / \mathrm{CD}^{-} 6^{+} \mathrm{NK}$ 
$\mathbf{F}$
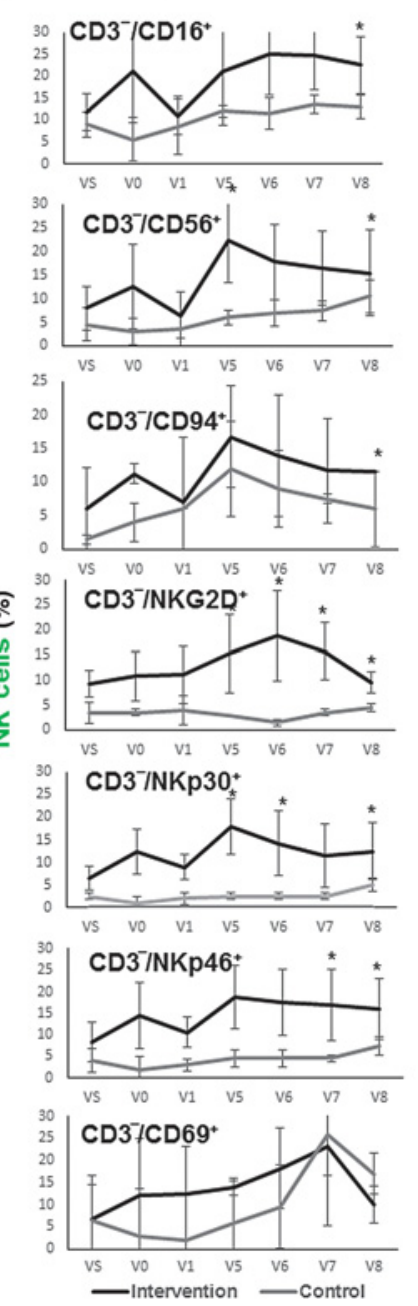

Nonresponder
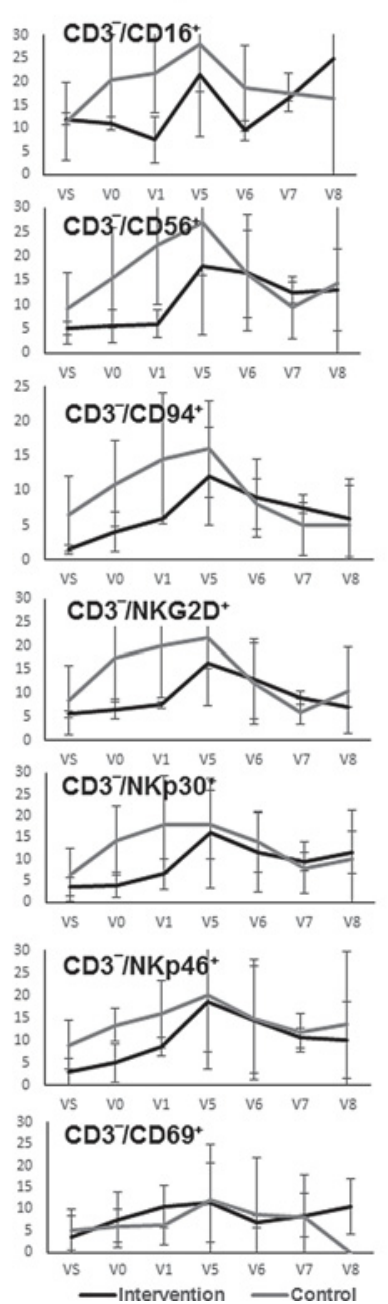

G

INT

CTRL

Nonresponder Responder Nonresponder Responder
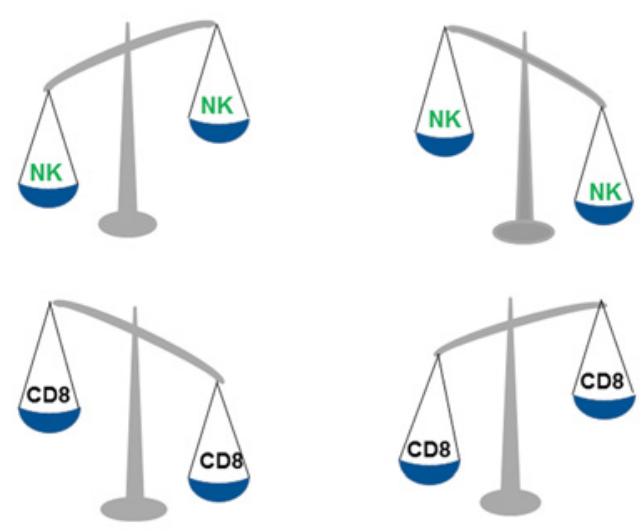

Figure 1.

(Continued.) F, Comparison of the proportion of NK-cell subsets in responders and nonresponders of the INT versus CTRL group at visits VS (screening), VO (after RCT), V1 (1-2 months after randomization), V5 (3-4 months after randomization), V6 (6-7 months after randomization), V7 (9-12 months after randomization), and V8 (18 months after randomization). The following NK-cell subsets were assessed: $\mathrm{CD}^{-} / \mathrm{CD}^{-} 6^{+}, \mathrm{CD}^{-} / \mathrm{CD}^{-} 6^{+}, \mathrm{CD}^{-} / \mathrm{CD}^{-} 4^{+}, \mathrm{CD}^{-} /$ $\mathrm{NKG}_{2} \mathrm{D}^{+}, \mathrm{CD}^{-} / \mathrm{NKp}^{+} 0^{+}, \mathrm{CD}^{-} / \mathrm{CD}_{4} 6^{+}, \mathrm{CD}^{-} / \mathrm{CD} 9^{+}$. Responders of the INT arm, $n=4$; nonresponders of the INT arm, $n=2$; responders of the CTRL arm, $n=2$; nonresponders of the CTRL arm, $n=5$. ${ }^{*}, P \leq 0.05$. G, Schematic representation of the distribution of NK cells (green) and CD ${ }^{+}$cytotoxic T cells in nonresponders and responders of the INT and CTRL arms.

cells, as well as the proportion of NK cells are shown in Table 1B. Overall, the number of reinfused NK cells ranging from $1.04 \times 10^{8}$ (minimum) to $5.63 \times 10^{8}$ (maximum) increased between the first and third reinfusion cycles and remained elevated after the fourth cycle (Table 1B). The proportion of $\mathrm{CD} 3^{-} / \mathrm{CD} 56^{+}$ NK cells in the leukapheresis products ranged between $6 \%$ and $23 \%$. Peripheral blood was taken at study visits VS, V0, V1, V5, V6, $\mathrm{V} 7$, and V8.

\section{Patient demographics and disposition}

The median age of the patients was 63 years (range, 56-76 years). One patient of the CTRL arm was randomized, but no further data were collected. Of the 8 patients allocated to the INT arm, 2 were excluded from the study prior to first administration of the study medication due to medical conditions (SAE: pneumonia, pyrexia) which were identified before the first intended treatment cycle. These patients were considered in the description of the study population and for assessment of safety, but were excluded from the efficacy analyses. Of the 6 remaining patients, 5 completed all $4 \mathrm{NK}$ cell treatment cycles and 1 patient received only one NK-cell transfer. Although leukapheresis was performed 3 times, reinfusion was possible only once because the upregulation of the CD94 expression on NK cells (as a potency marker) failed the criteria twice (01 103; Table 1B).

\section{Quality-of-life (QoL-C30)}

Results for the sum score of the QLQ-C30 questionnaire of the INT and CTRL group are presented as means, standard deviations, differences in means $(95 \% \mathrm{CI})$, numbers of eligible questionnaires, and $P$ values for both study groups for visits $1,6,7,8$, 
Table 1A Patient characteristics.

\begin{tabular}{ll}
\hline Patient characteristics & $\mathbf{N}=\mathbf{1 6}$ \\
\hline Gender & \\
Male & 9 \\
Female & 7 \\
Age & $56-76$ years (mean 63 years) \\
Histology squamous NSCLC & 16 \\
Stage & \\
IIIla & 8 \\
IIIb & 8 \\
Recruitment & 8 (drop-out 2) \\
INT arm & 8 (drop-out 1) \\
CTRL arm &
\end{tabular}

and 9 (Table 1C). No statistically significant differences were observed between both study groups.

\section{Toxicities/adverse events}

A toxic event was defined as an AE of grade 3 or higher according to NCI CTCEv4.0. Overall, 8 AEs (all grade 3 ) were documented in 4 different patients and deemed unrelated to the study medication, 6 in the INT group ( 3 patients) and 2 in the CTRL group (1 patient). A total of 40 AEs were reported in 10 patients, who experienced at least one AE, 2 in the CTRL group, and 3 in the INT group (Supplementary Table S2). No SAE was related to the IMP, and no suspected unexpected serious adverse reactions (SUSAR) were reported in the study. Five protocol violations in 4 patients, who were excluded from the per protocol set, were rated as major (i.e., no laboratory samples taken at screening visit, no reinfusion of blood due to failed activation of NK cells-twice in 1 patient). No patient died between randomization and the final tumor assessment which was undertaken 18 months after randomization (V8).

Routine laboratory parameters, such as differential blood cell counts, hemoglobin concentration, RBC parameters, PLT and WBC counts, AST/SGOT, ALT/SGPT, $\gamma$-GT, LDH, and sodium, remained within normal ranges throughout the therapeutic interventions and in the follow-up period in all patients (data not shown). However, 2 patients of the INT group showed increased blood creatinine levels, and decreased blood potassium levels were observed in 1 patient in the CTRL group. Side effects of the leukapheresis were minimal and most likely not related to the NK-cell therapy.

\section{Responses}

A total of 16 patients ( 7 females and 9 males) with firstly diagnosed histologically proven, $\mathrm{mHsp} 70$-positive NSCLC ( 8 patients stage IIIa, 8 patients stage IIIb) who were at least progression-free after RCT were randomized into the CTRL ( 8 patients) and the INT ( 8 patients) arms of the phase II clinical trial between November 2014 and August 2017. Tumor assessments according to RECIST1.1 (RC1.1) and irRC were conducted 1 to 2 months after RCT when radiation-induced pneumonitis starts to decrease, in both groups following clinical routine CT in the follow-up period 3-4 (V5), 6-7 (V6), 9-12 (V7), and 18 (V8) months after randomization. Tumor progression was observed in 2 patients of the INT arm, one of them receiving only 1 NK-cell cycle, and 5 patients in the CTRL arm. Kaplan-Meier curves for PFS are shown in Fig. 1B. Estimated 1-year probabilities for PFS are $67 \%(95 \% \mathrm{CI}, 19 \%-90 \%)$ for the INT group and 33\% (95\% CI, $5 \%-68 \%)$ for the CTRL group ( $P=0.36$, one-sided log-rank test). The estimated HR between both groups was 0.77 (95\% CI, 0.17-3.45, Cox regression). In the per protocol population, estimated 1-year survival probabilities were $80 \%(95 \% \mathrm{CI}, 20 \%-97 \%)$ in the INT group and $25 \%(95 \% \mathrm{CI}, 1 \%-67 \%)$ in the CTRL group (HR, 0.43; 95\% CI, 0.07-2.63).

At the last documented visit, 1 patient of the INT group had an immune-related complete response (irCR), 1 patient had a partial response (irPR), 2 patients had stable disease (irSD), and 2 patients had progressive disease (irPD) at V6 and V7 (Table 1D). In the CTRL group (Table 1E), 1 patient had an irPR, 1 patient had irSD until V6, and 5 patients had irPD. One patient of the CTRL group was a dropout before V3. Due to the fixed end of the study at 18 months after randomization, no further follow-up data are available.

In total, 7 patients showed PD. According to RECIST1.1 in the INT arm, 2 patients had new lesions subcarinal and in the lymph node (LN) and a nontarget lesion (NTL; Table 1D). In the CTRL group, 2 patients had new lesions (NL) in the lymph node and mediastinum, 1 patient had a target lesion (TL) and intrapulmonary metastasis (TL+NL), and 2 patients had target lesions in the lung (Fig. 1E). Representative CT and PET-CT images of patients (INT arm) who showed either CR, PR,

Table 1B. Number of reinfused peripheral lymphocytes (PBL), $\mathrm{CD}^{-} / \mathrm{CD} 56^{+} \mathrm{NK}$ cells at the different reinfusion cycles of the INT group.

\begin{tabular}{|c|c|c|c|c|c|c|c|c|}
\hline $\begin{array}{l}\text { Reinfusion cycle } \\
\#\end{array}$ & $\begin{array}{l}1 \\
\text { PBL }\end{array}$ & NK & $\begin{array}{l}2 \\
\text { PBL }\end{array}$ & NK & $\begin{array}{l}3 \\
\text { PBL }\end{array}$ & NK & $\begin{array}{l}4 \\
\mathrm{PBL}\end{array}$ & NK \\
\hline $\mathrm{CD}^{-} / \mathrm{CD}^{-} 6^{+}$ & $\times 10^{9}$ & $\times 10^{8}$ & $\times 10^{9}$ & $\times 10^{8}$ & $\times 10^{9}$ & $\times 10^{8}$ & $\times 10^{9}$ & $\times 10^{8}$ \\
\hline 01103 & 0.69 & 0.26 & 0.18 & 0.31 & 0.18 & 1.23 & - & - \\
\hline $\mathrm{CD3}^{-} / \mathrm{CD} 56^{+}$ & No infusion & $4 \%$ & No infusion & $6 \%$ & & $7 \%$ & & \\
\hline 02201 & 1.21 & 1.04 & 1.35 & 1.95 & 1.21 & 2.06 & 1.16 & 2.02 \\
\hline $\mathrm{CD}^{-} / \mathrm{CD}^{-} 6^{+}$ & & $13 \%$ & & $12 \%$ & & $14 \%$ & & $15 \%$ \\
\hline 02202 & 1.67 & 2.33 & 1.26 & 1.38 & 1.44 & 2.17 & 2.23 & 3.64 \\
\hline $\mathrm{CD}^{-} / \mathrm{CD} 56^{+}$ & & $14 \%$ & & $13 \%$ & & $14 \%$ & & $16 \%$ \\
\hline 03303 & 1.21 & 1.7 & 2.5 & 3.5 & 3.5 & 5.3 & 2.9 & 4.0 \\
\hline $\mathrm{CD3}^{-} / \mathrm{CD} 6^{+}$ & & $10 \%$ & & $14 \%$ & & $15 \%$ & & $16 \%$ \\
\hline 05501 & 1.35 & 1.11 & 3.21 & 4.27 & 2.14 & 2.04 & 2.6 & 2.72 \\
\hline $\mathrm{CD}^{-} / \mathrm{CD} 6^{+}$ & & $6 \%$ & & $10 \%$ & & $11 \%$ & & $13 \%$ \\
\hline 05504 & 5.7 & 4.2 & 5.4 & 5.28 & 4.9 & 5.63 & 3.5 & 4.32 \\
\hline $\mathrm{CD}^{-} / \mathrm{CD} 56^{+}$ & & $21 \%$ & & $22 \%$ & & $21 \%$ & & $23 \%$ \\
\hline
\end{tabular}

Note: Viability of the reinfused cells was always $>90 \%$. Leukapheresis products 1 and 2 of patient 01103 were not reinfused because the upregulation of the CD94 expression as a potency marker failed the criteria. 
Table 1C. Summary of the QLQ-C30 sum score for both study groups at different visits.

\begin{tabular}{|c|c|c|c|c|c|c|}
\hline Visit & Group & $N$ & Mean & $\begin{array}{l}\text { Standard } \\
\text { deviation }\end{array}$ & Diff in means $(95 \% \mathrm{Cl})$ & $P$ value \\
\hline \multirow[t]{2}{*}{1} & INT & 7 & 67.4 & 16.7 & -6.8 & 0.547 \\
\hline & CTRL & 6 & 74.2 & 21.5 & ( -31.1 to 17.5 ) & \\
\hline \multirow[t]{2}{*}{6} & INT & 3 & 92.5 & 4.1 & 9.9 & 0.140 \\
\hline & CTRL & 7 & 82.6 & 14.6 & $(-4.1$ to 23.9$)$ & \\
\hline \multirow[t]{2}{*}{7} & INT & 6 & 87.0 & 6.2 & 12.0 & 0.188 \\
\hline & CTRL & 6 & 75.0 & 18.8 & $(-7.7$ to 31.8$)$ & \\
\hline \multirow[t]{2}{*}{8} & INT & 5 & 77.8 & 19.6 & 5.2 & 0.734 \\
\hline & CTRL & 5 & 72.6 & 26.3 & $(-29.1$ to 39.5$)$ & \\
\hline \multirow[t]{2}{*}{9} & INT & 2 & 84.5 & 9.8 & & 0.687 \\
\hline & CTRL & 3 & 78.4 & 20.3 & $(-37.8$ to 49.9$)$ & \\
\hline
\end{tabular}

Note: Presented are the number of available questionnaires for each study group $(N)$, mean values, standard deviations, differences in means between study groups with $95 \% \mathrm{Cl}$, and the $P$ value of the two-sided $t$ test comparing group means.

or PD are shown in Fig. 1C. In the top plot, a mediastinal lymph node and a tumor in the left hilum which are classified as target lesions are clearly visible at VS. Both lesions are not visible in the following examinations at V1 after RCT and V8, 18 months after randomization, resulting in a CR. In the middle plot, a large tumor mass in the right lung is visible at VS. Obviously, this mass showed a drastic shrinkage in the follow-up period at V8, although a small residuum is still visible, resulting in a PR. In the bottom plot, a lymph node in the right hilum is visible at VS. Due to a new lesion which appeared in the follow-up period at V8, a PD was diagnosed in this patient.

Overall, plasma/serum Hsp70 levels at diagnosis (VS, $11.2 \pm 3.4$ $\mathrm{ng} / \mathrm{mL})$ were above those of healthy individuals $(>7.4 \mathrm{ng} / \mathrm{mL})$ in all patients. At randomization (V1, 1-2 months after RCT) and 3 to 4 months after randomization (V5), Hsp70 plasma/serum levels dropped to $10.2 \pm 3.8$ and $10.6 \pm 5.2 \mathrm{ng} / \mathrm{mL}$, respectively. A separate comparison of responders and nonresponders of the INT as well as the CTRL group revealed an increase in the Hsp70 values after RCT (V1) followed by a drop below initial levels at V5 in responders, whereas in nonresponders, Hsp70 levels dropped after RCT, but increased at V5 (Table 1F).

\section{$B, T, N K T$, and NK-cell subsets in responders and nonresponders in the INT and CTRL groups}

The composition of major lymphocyte subpopulations of all study patients was determined at the following visits: screening for mHsp70 (VS), after RCT (V0), 1-2 months after RCT at randomization (V1), 3-4 months after randomization (V5), 6-7 months after randomization (V6), 9-12 months after randomization (V7), and 18 months after randomization (V8).
Proportions of $\mathrm{CD}^{-} / \mathrm{CD} 19^{+} \mathrm{B}$ cells, $\mathrm{CD}^{+} / \mathrm{CD} 45^{+} \mathrm{T}$ cells, $\mathrm{CD}^{+} / \mathrm{CD}^{+} \mathrm{T}$ helper cells, and $\mathrm{CD}^{+} / \mathrm{CD}^{+}$cytotoxic $\mathrm{T}$ cells between VS and V8 in responders (CR, SD, PR; $n=4)$ and nonresponders (PD; $n=2)$ in the INT group did not differ significantly (Fig. 1D, left plot). With respect to $\mathrm{CD}^{+} / \mathrm{CD}^{+} /$ $\mathrm{CD}_{25}{ }^{+} / \mathrm{FoxP}^{+}$Tregs, nonresponders compared with responders showed elevated mean ratios at V1 (4.9\% vs. $1.6 \%)$ and V7 (5.6\% vs. $2.1 \%)$. In line with healthy individuals, the percentage of $\mathrm{CD} 4^{+} \mathrm{T}$ cells was always above that of $\mathrm{CD}^{+}$cytotoxic $\mathrm{T}$ cells throughout the entire clinical course (VS-V8) with CD4/CD8 ratios ranging between 4.4 and 3.5. With respect to major NKT subpopulations such as $\mathrm{CD}^{+} / \mathrm{CD}_{16}{ }^{+}, \mathrm{CD}^{+} / \mathrm{CD}^{+} 6^{+}$, and $\mathrm{CD}^{+} / \mathrm{NKG}^{2} \mathrm{D}^{+}$cells, no significant differences were observed in responders and nonresponders of the INT arm (Fig. 1D, left plot).

Similar to the INT group, no major differences in the proportion of $\mathrm{CD}^{-} / \mathrm{CD} 19^{+} \mathrm{B}$ cells, $\mathrm{CD}^{+} / \mathrm{CD} 5^{+} \mathrm{T}$ cells, $\mathrm{CD}^{+} / \mathrm{CD}^{+}{ }^{+} \mathrm{T}$ helper and $\mathrm{CD}^{+} / \mathrm{CD}^{+}$cytotoxic $\mathrm{T}$ cells, and $\mathrm{CD}^{+} / \mathrm{CD}^{+} / \mathrm{CD} 25^{+} / \mathrm{FoxP}^{+}$ Tregs were observed in responders (SD, PR; $n=2)$ and nonresponders (PD; $n=5$ ) of the CTRL group (Fig. 1D, right plot). However, decreased $\mathrm{CD} 4 / \mathrm{CD} 8$ ratios ranging between 0.22 and 0.78 between V1 and V8 were observed in responders of the CTRL group (Fig. 1E). Significantly increased proportions of $\mathrm{CD}^{+} / \mathrm{CD} 16^{+} \mathrm{NKT}$ cells were observed between $\mathrm{V} 5$ and $\mathrm{V} 7$, whereas that of $\mathrm{CD}^{+} / \mathrm{NKG}^{2} \mathrm{D}^{+} \mathrm{NKT}$ cells were found to be decreased in responders of the CTRL group (Fig. 1D, right plot).

The most striking differences were observed in the NK-cell subsets of the INT and CTRL groups. Overall, the percentage of $\mathrm{CD}^{-} / \mathrm{CD} 16^{+}, \mathrm{CD}^{-} / \mathrm{CD} 6^{+}, \mathrm{CD}^{-} / \mathrm{CD} 4^{+}, \mathrm{CD}^{-} / \mathrm{NKG}^{2} \mathrm{D}^{+}$, $\mathrm{CD}^{-} / \mathrm{NKp} 30^{+}, \mathrm{CD}^{-} / \mathrm{NKp}^{-} 6^{+}$, and activated $\mathrm{CD}^{-} / \mathrm{CD}^{-} 9^{+} \mathrm{NK}$ cells in responders of the INT group was always above that of

Table 1D. Tumor assessment in the INT group (INT, $n=6$ ) and localization of lesions at PD.

\begin{tabular}{llllllll}
\hline INT (NK cycles) & irRC & Visit & RC1.1 & Visit & Localization of lesions & Date & PFS months \\
\hline $01103(1)$ & irPD & V6 & PD & V6 & NL subcarinal & $11 / 2016$ & 4 \\
$02201(4)$ & irCR & $>$ V8 & CR & $>$ V8 & & $9 / 2016$ & 15 \\
$02202(4)$ & irSD & V8 & SD & V8 & & $6 / 2016$ & 9 \\
$03303(4)$ & irSD & $>$ V8 & SD & $>$ V8 & & $7 / 2017$ & 16 \\
$05501(4)$ & irPD & V6 & PD & V7 & NTL+NL LN & $5 / 2015$ & 6.5 \\
$05504(4)$ & irPR & V8 & SD & V8 & & $5 / 2018$ & 11 \\
\hline
\end{tabular}

Abbreviations: LN, lymph node; NL, new lesion; NTL, nontarget lesion; RC1.1, RECIST 1.1. 
Table 1E. Tumor assessment in the control group (CTRL, $n=7$ ) and localization of lesions at PD.

\begin{tabular}{lllllll}
\hline CTRL & irRC & Visit & RC1.1 & Visit & Localization of lesions & Date \\
\hline 01101 & irPD & V7 & PD & V7 & TL lung & $9 / 2015$ \\
01102 & irPD & V6 & PD & V6 & NL LN & $10 / 2016$ \\
02203 & irSD & V6 & SD & V6 & & 3 \\
03301 & irPD & V6 & PD & V6 & TL lung & $5 / 2016$ \\
03302 & irPD & $>$ V8 & PD & $>$ V8 & TL+NL intrapul mets & $4 / 2015$ \\
05502 & irPD & $>$ V8 & PD & $>$ V8 & NL mediastinum & $10 / 2016$ \\
05503 & irPR & $>$ V8 & PR & $>$ V8 & & $2 / 2018$ \\
\hline
\end{tabular}

Abbreviations: Intrapul mets, intrapulmonary metastasis; LN, Iymph node; NL, new lesion; RC1.1, RECIST 1.1; TL, target lesion.

nonresponders until V8 (Fig. 1D, left plot). In stark contrast to the INT group, significantly lower NK-cell counts at V5 were observed in responders of the CTRL group (who did not receive adoptive NK-cell transfer; Fig. 1D, right plot). After V5 the proportion of NK cells in the CTRL arm dropped until V8, whereas that of the INT arm remained to be elevated. Therefore, we speculate that the increased ratios of NK cells in the responders of the INT arm are most likely related to the adoptive transfer of the ex vivo-stimulated NK cells. An increased proportion of $\mathrm{CD}^{-} /$ $\mathrm{CD} 9^{+} \mathrm{NK}$ cells documents the activation status of the NK cells after V5. A comparison of the ratios of immune cell subsets in responders versus nonresponders revealed a drop in all NK-cell subpopulations in nonresponders at PD in the INT arm, but not in the CTRL arm (Supplementary Table S3).

\section{CD4/CD8 T cells, NKT, and NK-cell subsets in responders of the INT and CTRL arms}

$\mathrm{CD} 4 / \mathrm{CD} 8$ ratios of a representative responder of the INT and CTRL arms indicate values ranging from 3.5 to 4.4 and 0.22 to 0.78 , respectively (Fig. 1E). The percentage of all major NKT subsets such as $\mathrm{CD}^{+} / \mathrm{CD}^{+} 6^{+}, \mathrm{CD}^{+} / \mathrm{CD} 6^{+}, \mathrm{CD}^{+} / \mathrm{CD} 4^{+}, \mathrm{CD}^{+} /$ $\mathrm{NKG}_{2} \mathrm{D}^{+}$, and $\mathrm{CD}^{+} / \mathrm{CD} 9^{+}$cells remained stably low between $\mathrm{V} 1$ and V8 in the INT arm, whereas, in the CTRL arm, the percentages of $\mathrm{CD}^{+} / \mathrm{CD} 16^{+}, \mathrm{CD}^{+} / \mathrm{NKG} \mathrm{D}^{+}$, and $\mathrm{CD}^{+} / \mathrm{CD} 9^{+}$NKT cells were elevated in responders.

Between randomization (V1), NK-cell therapy (V5), and in the follow-up period 6-7 (V6) and 18 months (V8) after randomization, a massive upregulation in $\mathrm{CD}^{-} / \mathrm{CD}^{+} 6^{+}(\mathrm{V} 6,4 \mathrm{x} ; \mathrm{V} 8,4 \mathrm{x})$, $\mathrm{CD}^{-}{ }^{-} \mathrm{CD}^{2} 6^{+}\left(\mathrm{V} 5,8.6 \mathrm{x}\right.$; V8, 9x), $\mathrm{CD}^{-} / \mathrm{CD}^{+} 4^{+}(\mathrm{V} 5,1.8 \mathrm{x}$; V8 4.2x), and $\mathrm{CD}^{-} / \mathrm{NKG}^{+} \mathrm{D}^{+}(\mathrm{V} 5,3.6 \mathrm{x}$; V8, 3.3x) NK-cell subsets was observed in responders of the INT arm (Fig. 1E). In contrast, levels of $\mathrm{CD}^{-} / \mathrm{CD}^{2} 6^{+}, \mathrm{CD}^{-} / \mathrm{CD} 4^{+}$, and $\mathrm{CD}^{-} / \mathrm{NKG}^{2} \mathrm{D}^{+} \mathrm{NK}$-cell

Table 1F. Hsp70 plasma/serum levels in responder and nonresponder patients of the INT and CTRL arms at visits VS, V1, and $\mathrm{V} 5$.

\begin{tabular}{llll}
\hline Hsp70 & Vs $(\mathbf{n g} / \mathbf{m L})$ & V1 & V5 \\
\hline INT & & & \\
$\quad$ Responder & $13.6 \pm 5.2$ & $15.0 \pm 7.2$ & $11.1 \pm 6.1$ \\
$\quad$ Nonresponder & $10.3 \pm 0.7$ & $5.6 \pm 0.5$ & $9.5 \pm 3.0$ \\
CTRL & & & \\
$\quad$ Responder & $11.8 \pm 3.1$ & $12.8 \pm 0.9$ & $8.0 \pm 6.0$ \\
$\quad$ Nonresponder & $9.2 \pm 4.5$ & $7.4 \pm 6.7$ & $13.7 \pm 5.8$ \\
All patients & $11.2 \pm 3.4$ & $10.2 \pm 3.8$ & $10.6 \pm 5.2$ \\
\hline
\end{tabular}

Note: VS, screening for Hsp70; V1, randomization 1-2 months after RCT; V5, 3-4 months after randomization. subsets remained at low levels (1\% to 6\%) between V1 and V8 in responders of the CTRL group (Fig. 1E).

\section{NK-cell subsets in responders and nonresponders of the INT and CTRL arms}

A comparison of all tested NK-cell subsets in responders and nonresponders of the INT and CTRL arms throughout the entire clinical course (VS-V8) revealed significantly higher proportions of $\mathrm{CD}^{-} / \mathrm{CD} 16^{+}, \mathrm{CD}^{-} / \mathrm{CD} 56^{+}, \mathrm{CD} 3^{-} / \mathrm{CD} 4^{+}, \mathrm{CD}^{-} / \mathrm{NKG} \mathrm{D}^{+}$, $\mathrm{CD}^{-} / \mathrm{NKp} 30^{+}$, and $\mathrm{CD}^{-} / \mathrm{NKp} 46^{+} \mathrm{NK}$ cells in responders of the INT group than in responders of the CTRL arm at V8 (Fig. 1F). Lower proportions of NK cells were present in nonresponders of the INT arm compared with nonresponders of the CTRL arm between VS and V5 (first follow-up after 3-4 months). Between V5 and V8 in the follow-up period (6-18 months after randomization), the percentages of all NK-cell subsets (apart from $\mathrm{CD}^{-} / \mathrm{CD} 16^{+} \mathrm{NK}$ cells) dropped in all nonresponders of the INT and CTRL arms.

Overall, the PFS of patients who received NK-cell therapy (INT) was improved compared with that of patients who only received RCT (CTRL), and it was apparent that clinical responses in the INT group were associated with an increase in the prevalence of activated NK cells (Fig. 1G).

\section{Discussion}

Patients with NSCLC are typically treated with combined regimens such as RCT, targeted therapies, and/or immune therapies such as those that employ monoclonal antibodies to target the programmed cell death protein-1 (PD-1) on $\mathrm{CD}^{+} \mathrm{T}$ lymphocytes and NK cells, or their ligand, PD-L1, on cancer cells-so-called "checkpoint inhibitors." Although the introduction of immune checkpoint blockade has improved clinical outcomes (19-21), a relevant proportion of patients do not adequately respond to this therapy due to immunosuppressive mechanisms driven by hypoxia and other factors in the tumor microenvironment (22), the absence of antitumor-specific effector cells, immune escape mechanisms (23), and other, as yet, unidentified reasons.

A global profiling of cell surface antigen expression and flow cytometric analysis using an Hsp70-specific mAb (cmHsp70.1) or a Fab fragment derived thereof $(6,24)$ has identified $\mathrm{mHsp} 70$ as a tumorspecific target. Depending on its subcellular distribution and expression density, Hsp70 fulfills different prosurvival functions (25). On the one hand, high cytosolic Hsp70 levels can impede apoptotic pathways in tumor cells (25), and elevated mHsp70 expression densities are associated with resistance to radiotherapy (26). On the other hand, mHsp70 has been identified as a trigger to activate NK cells in the presence of IL2, and a high mHsp70 density supports the capacity of Hsp70-activated NK cells to kill tumor cells $(1,6,20,27,28)$. NK cells 
play a crucial role in the first-line defense against cancer (29-32). Studies have indicated that the OS of patients with oropharyngeal cancer positively correlates with high numbers of tumor-infiltrating $\mathrm{CD}^{-} / \mathrm{CD} 56^{+} \mathrm{NK}$ cells (33) that recognize antigens in the absence of $\mathrm{MHC}$ molecules via activatory receptors belonging to the C-type lectin family (34-36).

Herein, the efficacy of adoptively transferred, ex vivo-stimulated NK cells in patients with advanced NSCLC was studied. Because the OS of patients with mHsp70-positive tumors is generally lower than that of their mHsp70-negative counterparts (37), only patients with mHsp70-positive tumors were randomized into the study. As viable tumor cells with an mHsp70-positive phenotype actively release exosome-associated Hsp70 into the extracellular milieu (38), the mHsp70 status of tumors was determined in the blood by the lipHsp70 ELISA (17). A limitation of the blood-based assay is that it is unable to distinguish exosomal Hsp70 derived from viable tumor cells and free Hsp70 derived from dying tumor cells.

Previous studies revealed that patients with solid tumors frequently have dysfunctional NK cells (15), and that after 4 repeated reinfusion cycles, activated NK cells can be detected in the peripheral blood $(13,14)$. Therefore, 4 reinfusion cycles were given in the study. Exosomal Hsp70 derived from mHsp70-positive tumor cells in the presence of proinflammatory cytokines can attract NK cells and stimulate their cytolytic activity, in vitro (38). This mechanism might also be active in vivo in responding patients after adoptive transfer of mHsp70-targeting NK cells. Together with the finding that NK stimulation is more efficient when PBLs instead of sorted NK cells are incubated with TKD/IL2 (unpublished observation), we hypothesize that due to a yet undefined cross-presentation of Hsp70-peptide, in vivo, resting NK cells become stimulated in the body of responding patients.

All study patients with advanced mHsp70-positive NSCLC received RCT for tumor debulking and to increase the density of damageassociated molecular patterns (DAMP), including Hsp70 in the circulation. Therapy-induced cellular stress provides critical cues for activating the innate immune system (39), and Hsp70 released from stressed tumor cells has been found to support antitumor immunity via TLR4 pathway (40). In line with this hypothesis, tumor response was associated with increased Hsp70 concentrations in the peripheral blood after therapy which dropped below initial levels after adoptive transfer of ex vivo TKD/IL2-stimulated NK cells.

The repeated treatments with autologous NK cells every 2 to 6 weeks directly after RCT were well tolerated, and no severe toxicities and no differences in QoL were observed in both arms of the open study. Due to ethical restrictions, only patients of the INT, but not of the CTRL, group received leukapheresis. The absolute number and percentage of $\mathrm{CD}^{-} / \mathrm{CD} 56^{+} \mathrm{NK}$ cells gradually increased in the peripheral blood of patients from the first to the fourth stimulation cycle, thereby indicating that the ex vivo stimulation with TKD/IL2 concomitant with the release of DAMPs and Hsp70 might support NK-cell proliferation, in vivo. An increased cell surface density of activating receptors including CD94/NKG2C which serves as a surrogate marker for the cytolytic activity of NK cells against mHsp70-positive tumor cells $(35,36)$ was shown in all reinfused cellular products.

Compared with the CTRL arm in which only 2 patients showed clinical responses (PR, SD) and 5 patients had $\mathrm{PD}$, the clinical outcome for patients in the INT arm was markedly better, most likely due to the adoptive transfer of activated NK cells: one patient had a CR, 1 patient a $\mathrm{PR}, 2$ patients had SD, and only 1 patient experienced $\mathrm{PD}$ at the last documented visit 18 months after randomization. Because tumor progression was associated with a drastic drop in the ratio of NK cells, it was assumed that NK cells are involved in tumor control.

Historically, RCT was considered as being immunosuppressive because of large radiation fields that included substantial volumes of the blood and bone marrow (41). However, advances in radiotherapy have minimized normal tissue and immune cell damage, as a result of which major parts of the bone marrow are spared and immunosuppression reduced. In preclinical models and in some clinical settings, RCT has been shown to induce immunogenic tumor cell death which in turn can elicit abscopal effects which can support the development of protective antitumor immunity and thereby improve clinical outcome (42-44). In the present study, RCT did not significantly alter the immune cell composition in responders of the INT and CTRL arms. Preclinical studies are ongoing to determine whether hypofractionated radiation regimens might lead to a greater enhancement of mHsp70 release which correlates with an enhanced immunity.

As extracellular Hsp70 has previously been shown to predict the mHsp70 status in patients with NSCLC, mHsp70 positivity of the patient's tumor at diagnosis was confirmed by elevated exosomal Hsp70 concentrations (45). Because only patients who were progression free after RCT were included into the study, it was expected that extracellular Hsp70 levels after RCT are increased as a sign of tumor cell killing. As predicted, Hsp70 concentrations in the blood increased in all responders. The presence of extracellular Hsp70 derived from stressed tumor cells may also drive antitumor immune responses (40). In the presence of proinflammatory cytokines, Hsp70 cannot only attract NK cells but also stimulate their cytolytic activity (38). Patients who did not show an increase in extracellular Hsp70 after RCT showed neither an immune nor antitumor response.

In order to study the immunologic effects induced by RCT and NK-cell therapy in more detail, the composition of major lymphocyte subpopulations during the whole clinical course was assessed. Interestingly, the improved clinical outcomes (estimated PFS) for patients in the INT group were associated with an increased prevalence of NK cells and were most likely mediated by activated NK cells and not by $\mathrm{CD}^{+}$cytotoxic T cells. In contrast, clinical responses in the 2 patients of the CTRL group were associated with an increased prevalence of $\mathrm{CD}^{+}$cytotoxic $\mathrm{T}$ cells, with the percentage of NK cells remaining low throughout the whole course of study. In an upcoming trial, it remains to be determined whether a combinatorial therapy consisting of RCT, NK cells, and immune checkpoint inhibitors might further improve the outcome, as previously shown in preclinical models (46) and a case study (18).

\section{Disclosure of Potential Conflicts of Interest}

G. Multhoff reports a patent for MU03A15P-EP pending (patent of multimmune $\mathrm{GmbHh}$ ). A.G. Pockley reports that he is the Chief Executive Officer (CEO) of multimmune $\mathrm{GmbH}$, Munich, Germany and that multimmune $\mathrm{GmbH}$ holds issued patents (EP 1706 423; EP 2070 947; EP 2070 947; US 7,700,737) and has pending patents (US 16/636,741; PCT/EP2018/073496; CA 3,071,217) in areas broadly relevant to the work. C. Blankenstein reports grants from BMBF during the conduct of the study. M. Hildebrandt reports formal research contract as CMO with the first author (G. Multhoff) as authorizing person to arrange the manufacture of the Investigational Medicinal Product. R. Fietkau reports grants and personal fees from AstraZeneca, grants and personal fees from MSD, grants and personal fees from Merck, personal fees from Novartis, personal fees from Sennewald, and grants and personal fees from Novocure outside the submitted work. R. Huber reports grants from German Ministry of Education and Research, grants and personal fees from AstraZeneca, personal fees from Boehringer Ingelheim, personal fees from BristolMyers Squibb, personal fees from Pfizer, personal fees from Lilly, personal fees from Roche, personal fees from Takeda, personal fees from Novartis, personal fees from Celgene, personal fees from Abbvie, personal fees from Tesaro, and personal 
fees from Bayer outside the submitted work. B. Haller reports grants from Bundesministerium für Bildung und Forschung (BMBF) during the conduct of the study. S.E. Combs reports personal fees and non-financial support from Roche, personal fees and non-financial support from AstraZeneca, personal fees and non-financial support from Medac, personal fees and non-financial support from Dr. Sennewald Medizintechnik, personal fees and non-financial support from Elekta, personal fees and non-financial support from Accuray, personal fees and non-financial support from BMS, personal fees and non-financial support from Brainlab, personal fees and nonfinancial support from Daiichi Sankyo, and personal fees and non-financial support from Icotec outside the submitted work. No potential conflicts of interest were disclosed by the other authors.

\section{Authors' Contributions}

G. Multhoff: Conceptualization, resources, supervision, funding acquisition, validation, writing-original draft, writing-review and editing. S. Seier: Investigation, methodology. S. Stangl: Resources, supervision, investigation, methodology. W. Sievert: Validation, methodology. M. Shevtsov: Investigation, methodology. C. Werner: Investigation, methodology. A.G. Pockley: Data curation, writing-review and editing. C. Blankenstein: Data curation, formal analysis. M. Hildebrandt: Data curation, investigation. R. Offner: Formal analysis, investigation. N. Ahrens: Formal analysis, investigation. K. Kokowski: Formal analysis, investigation. M. Hautmann: Investigation. C. Rödel: Formal

\section{References}

1. Ferlay J, Soerjomataram I, Dikshit R, Eser S, Mathers C, Rebelo M, et al. Cancer incidence and mortality worldwide: sources, methods and major patterns in GLOBOCAN 2012. Int J Cancer 2015;136:E359-86.

2. Oberije C, De Ruysscher D, Houben R, van de Heuvel M, Uyterlinde W, Deasy $\mathrm{JO}$, et al. A validated prediction model for overall survival from stage III nonsmall cell lung cancer: toward survival prediction for individual patients. Int J Radiat Oncol Biol Phys 2015;92:935-44.

3. Ahn JS, Ahn YC, Kim JH, Lee CG, Cho EK, Lee KC, et al. Multinational randomized phase III trial with or without consolidation chemotherapy using docetaxel and cisplatin after concurrent chemoradiation in inoperable stage III non-small-cell lung cancer: KCSG-LU05-04. J Clin Oncol 2015;33:2660-6.

4. Huber RM, Flentje M, Schmidt M, Pollinger B, Gosse H, Willner J, et al. Simultaneous chemoradiotherapy compared with radiotherapy alone after induction chemotherapy in inoperable stage IIIA or IIIB non-small-cell lung cancer: study CTRT99/97 by the Bronchial Carcinoma Therapy Group. J Clin Oncol 2006;24:4397-404.

5. Travis WD. Pathology of lung cancer. Clin Chest Med 2011;32:669-92.

6. Stangl S, Gehrmann M, Riegger J, Kuhs K, Riederer I, Sievert W, et al. Targeting membrane heat-shock protein 70 (Hsp70) on tumors by $\mathrm{cmHsp} 70.1$ antibody. Proc Natl Acad Sci USA 2011;108:733-8.

7. Gehrmann M, Marienhagen J, Eichholtz-Wirth H, Fritz E, Ellwart J, Jaattela M, et al. Dual function of membrane-bound heat shock protein 70 (Hsp70), Bag-4, and Hsp40: protection against radiation-induced effects and target structure for natural killer cells. Cell Death Differ 2005;12:38-51.

8. Gehrmann M, Pfister K, Hutzler P, Gastpar R, Margulis B, Multhoff G. Effects of antineoplastic agents on cytoplasmic and membrane-bound heat shock protein 70 (Hsp70) levels. Biol Chem 2002;383:1715-25.

9. Multhoff G. Heat shock protein 72 (HSP72), a hyperthermia-inducible immunogenic determinant on leukemic K562 and Ewing's sarcoma cells. Int J Hyperthermia 1997;13:39-48.

10. Multhoff G, Botzler C, Wiesnet M, Muller E, Meier T, Wilmanns W, et al. A stress-inducible $72-\mathrm{kDa}$ heat-shock protein (HSP72) is expressed on the surface of human tumor cells, but not on normal cells. Int J Cancer 1995;61: 272-9.

11. Botzler C, Schmidt J, Luz A, Jennen L, Issels R, Multhoff G. Differential Hsp70 plasma-membrane expression on primary human tumors and metastases in mice with severe combined immunodeficiency. Int J Cancer 1998;77:942-8.

12. Multhoff G, Pfister K, Gehrmann M, Hantschel M, Gross C, Hafner M, et al. A 14-mer Hsp70 peptide stimulates natural killer (NK) cell activity. Cell Stress Chaperones 2001;6:337-44.

13. Krause SW, Gastpar R, Andreesen R, Gross C, Ullrich H, Thonigs G, et al. Treatment of colon and lung cancer patients with ex vivo heat shock protein 70-peptide-activated, autologous natural killer cells: a clinical phase I trial. Clin Cancer Res 2004;10:3699-707. analysis, investigation. R. Fietkau: Formal analysis, investigation. D. Lubgan: Formal analysis, investigation. R. Huber: Formal analysis, supervision, investigation. H. Hautmann: Investigation. T. Duell: Formal analysis, investigation. M. Molls: Investigation. H. Specht: Investigation. B. Haller: Data curation, software, formal analysis. M. Devecka: Formal analysis, investigation. A. Sauter: Data curation, formal analysis, investigation. S.E. Combs: Investigation.

\section{Acknowledgments}

This study was supported by BMBF "Innovative Therapies" (01GU0823), BMBF "Kompetenzverbund Strahlenforschung" (02NUK038A), BMWi (AiFproject GmbH, ZF4320102CS7), DFG-SFB824/3, DFG-STA1520/1-1, the German Research Foundation (DFG), multimmune $\mathrm{GmbH}$, and TUM within the funding program Open Access Publishing. We want to thank Maximilian Dobrunz (M.A.), Jessica Pelzel, Christine Becke, and Anett Lange for excellent technical assistance.

The costs of publication of this article were defrayed in part by the payment of page charges. This article must therefore be hereby marked advertisement in accordance with 18 U.S.C. Section 1734 solely to indicate this fact.

Received March 27, 2020; revised May 15, 2020; accepted July 21, 2020; published first September 1, 2020.

14. Milani V, Stangl S, Issels R, Gehrmann M, Wagner B, Hube K, et al. Anti-tumor activity of patient-derived NK cells after cell-based immunotherapy-a case report. J Transl Med 2009;7:50.

15. Bucklein V, Adunka T, Mendler AN, Issels R, Subklewe M, Schmollinger JC, et al. Progressive natural killer cell dysfunction associated with alterations in subset proportions and receptor expression in soft-tissue sarcoma patients. Oncoimmunology 2016;5:e1178421.

16. Specht HM, Ahrens N, Blankenstein C, Duell T, Fietkau R, Gaipl US, et al. Heat shock protein 70 (Hsp70) peptide activated natural killer (NK) cells for the treatment of patients with non-small cell lung cancer (NSCLC) after radiochemotherapy (RCTx) - from preclinical studies to a clinical phase II trial. Front Immunol 2015;6:162.

17. Breuninger S, Erl J, Knape C, Gunther S, Regel I, Rodel F, et al. Quantitative analysis of liposomal heat shock protein 70 (Hsp70) in the blood of tumor patients using an novel LipHsp70 ELISA. Clinical Cellular Immunology 2014;5: $2-10$.

18. Kokowski K, Stangl S, Seier S, Hildebrandt M, Vaupel P, Multhoff G. Radiochemotherapy combined with NK cell transfer followed by secondline PD-1 inhibition in a patient with NSCLC stage IIIb inducing long-term tumor control: a case study. Strahlenther Onkol 2019;195:352-61.

19. Antonia SJ, Villegas A, Daniel D, Vicente D, Murakami S, Hui R, et al. Durvalumab after chemoradiotherapy in stage III non-small-cell lung cancer. N Engl J Med 2017;377:1919-29.

20. Pardoll DM. The blockade of immune checkpoints in cancer immunotherapy. Nat Rev Cancer 2012;12:252-64.

21. Rizvi NA, Hellmann MD, Snyder A, Kvistborg P, Makarov V, Havel JJ, et al. Cancer immunology. mutational landscape determines sensitivity to PD-1 blockade in non-small cell lung cancer. Science 2015;348:124-8.

22. Vaupel P, Multhoff G. Adenosine can thwart antitumor immune responses elicited by radiotherapy: Therapeutic strategies alleviating protumor ADO activities. Strahlenther Onkol 2016;192:279-87.

23. Pockley AG, Vaupel P, Multhoff G. NK cell-based therapeutics for lung cancer. Expert Opin Biol Ther 2020;20:23-33.

24. Stangl S, Themelis G, Friedrich L, Ntziachristos V, Sarantopoulos A, Molls M, et al. Detection of irradiation-induced, membrane heat shock protein 70 (Hsp70) in mouse tumors using Hsp70 Fab fragment. Radiother Oncol 2011;99:313-6.

25. Jaattela M. Heat shock proteins as cellular lifeguards. Ann Med 1999;31:261-71.

26. Murakami N, Kuhnel A, Schmid TE, Ilicic K, Stangl S, Braun IS, et al. Role of membrane Hsp70 in radiation sensitivity of tumor cells. Radiat Oncol 2015; 10:149.

27. Brahmer JR, Drake CG, Wollner I, Powderly JD, Picus J, Sharfman WH, et al. Phase I study of single-agent anti-programmed death-1 (MDX-1106) in refractory solid tumors: safety, clinical activity, pharmacodynamics, and immunologic correlates. J Clin Oncol 2010;28:3167-75. 
28. Rizvi NA, Mazieres J, Planchard D, Stinchcombe TE, Dy GK, Antonia SJ, et al. Activity and safety of nivolumab, an anti-PD-1 immune checkpoint inhibitor, for patients with advanced, refractory squamous non-small-cell lung cancer (CheckMate 063): a phase 2, single-arm trial. Lancet Oncol 2015; $16: 257-65$.

29. Vivier E, Raulet DH, Moretta A, Caligiuri MA, Zitvogel L, Lanier LL, et al. Innate or adaptive immunity? The example of natural killer cells. Science 2011;331:44-9.

30. Morvan MG, Lanier LL. NK cells and cancer: you can teach innate cells new tricks. Nat Rev Cancer 2016;16:7-19.

31. Raulet DH, Gasser S, Gowen BG, Deng W, Jung H. Regulation of ligands for the NKG2D activating receptor. Annu Rev Immunol 2013;31:413-41.

32. Pross HF, Lotzova E. Role of natural killer cells in cancer. Nat Immun 1993;12: 279-92.

33. Wagner S, Wittekindt C, Reuschenbach M, Hennig B, Thevarajah M, Wurdemann $\mathrm{N}$, et al. CD56-positive lymphocyte infiltration in relation to human papillomavirus association and prognostic significance in oropharyngeal squamous cell carcinoma. Int J Cancer 2016;138:2263-73.

34. Kruse PH, Matta J, Ugolini S, Vivier E. Natural cytotoxicity receptors and their ligands. Immunol Cell Biol 2014;92:221-9.

35. Gross C, Hansch D, Gastpar R, Multhoff G. Interaction of heat shock protein 70 peptide with NK cells involves the NK receptor CD94. Biol Chem 2003; 384:267-79.

36. Gross C, Schmidt-Wolf IG, Nagaraj S, Gastpar R, Ellwart J, Kunz-Schughart LA, et al. Heat shock protein 70-reactivity is associated with increased cell surface density of CD94/CD56 on primary natural killer cells. Cell Stress Chaperones 2003;8:348-60

37. Stangl S, Tontcheva N, Sievert W, Shevtsov M, Niu M, Schmid TE, et al. Heat shock protein 70 and tumor-infiltrating NK cells as prognostic indicators for patients with squamous cell carcinoma of the head and neck after radiochemotherapy: a multicentre retrospective study of the german cancer consortium radiation oncology group (DKTK-ROG). Int J Cancer 2018; 142:1911-25.

38. Gastpar R, Gehrmann M, Bausero MA, Asea A, Gross C, Schroeder JA et al. Heat shock protein 70 surface-positive tumor exosomes stimulate migratory and cytolytic activity of natural killer cells. Cancer Res 2005; 65:5238-47.

39. Iannello A, Thompson TW, Ardolino M, Marcus A, Raulet DH. Immunosurveillance and immunotherapy of tumors by innate immune cells. Curr Opin Immunol 2016;38:52-8.

40. Chen T, Guo J, Han C, Yang M, Cao X. Heat shock protein 70, released from heatstressed tumor cells, initiates antitumor immunity by inducing tumor cell chemokine production and activating dendritic cells via TLR4 pathway. J Immunol 2009;182:1449-59.

41. Belka C, Ottinger H, Kreuzfelder E, Weinmann M, Lindemann M, LeppleWienhues A, et al. Impact of localized radiotherapy on blood immune cells counts and function in humans. Radiother Oncol 1999;50:199-204.

42. Demaria S, Golden EB, Formenti SC. Role of Local Radiation Therapy in Cancer Immunotherapy. JAMA Oncol 2015;1:1325-32.

43. Formenti SC, Demaria S. Systemic effects of local radiotherapy. Lancet Oncol 2009;10:718-26.

44. Siva S, MacManus MP, Martin RF, Martin OA. Abscopal effects of radiation therapy: a clinical review for the radiobiologist. Cancer Lett 2015;356:82-90.

45. Gunther S, Ostheimer C, Stangl S, Specht HM, Mozes P, Jesinghaus M, et al. Correlation of Hsp70 serum levels with gross tumor volume and composition of lymphocyte subpopulations in patients with squamous cell and adeno non-small cell lung cancer. Front Immunol 2015;6:556.

46. Shevtsov M, Pitkin E, Ischenko A, Stangl S, Khachatryan W, Galibin O, et al. Ex vivo Hsp70-activated NK cells in combination with PD-1 inhibition significantly increase overall survival in preclinical modesl of glioblastoma and lung cancer. Front Immunol 2019;10:454 
ACR American Association for Cancer Research

\section{Clinical Cancer Research}

\section{Targeted Natural Killer Cell-Based Adoptive Immunotherapy for the Treatment of Patients with NSCLC after Radiochemotherapy: A Randomized Phase II Clinical Trial}

Gabriele Multhoff, Sophie Seier, Stefan Stangl, et al.

Clin Cancer Res Published OnlineFirst September 1, 2020.

Updated version Access the most recent version of this article at: doi:10.1158/1078-0432.CCR-20-1141

E-mail alerts Sign up to receive free email-alerts related to this article or journal.

Reprints and To order reprints of this article or to subscribe to the journal, contact the AACR Publications Subscriptions Department at pubs@aacr.org.

Permissions To request permission to re-use all or part of this article, use this link http://clincancerres.aacrjournals.org/content/early/2020/09/01/1078-0432.CCR-20-1141. Click on "Request Permissions" which will take you to the Copyright Clearance Center's (CCC)

Rightslink site. 